Reprod. Nutr. Dévelop., 1983, 23 (2 A), 235-244.

\title{
The influence of 1,25-dihydroxycholecalciferol on the mineral content of foetal guinea pigs
}

\author{
D. DURAND, J.-P. BARLET, G. D. BRAITHWAITE $\left({ }^{*}\right)$
}

I.N.R.A. Theix, 63110 Beaumont, France.

(*) National Institute for Research in Dairying Shinfield, Reading, RG2 9AT, England.

Summary. The influence of 1,25-dihydroxycholecalciferol $10.05 \mu \mathrm{g} / \mathrm{kg} \mathrm{bw} /$ day, given I.M. for 10 days) on calcium transfer from dam to foetus and on foetal calcium and phosphate content was observed in 3 groups of 10 guinea pigs, one group on each of days 40,50 and 66 of gestation. At 40 and 50 days of gestation, 1,25-dihydroxycholecalciferol increased the calcium and phosphate content of the foetus. ${ }^{45} \mathrm{Ca}$ transfer from the dam to placenta (measured during a $30-90$ min period) was higher in treated than in control animals.

\section{Introduction.}

The biologically active metabolite of cholecalciferol, 1,25-dihydroxycholecalciferol $\left(1,25-(\mathrm{OH})_{2}-\mathrm{D}_{3}\right)$ is synthesized by successive hydroxylations of cholecalciferol in the liver and kidney (Fraser et Kodicek, 1970). However it has been demonstrated that nephrectomy of pregnant, vitamin D-deficient rats reduced but did not abolish the in vivo conversion of $\left[{ }^{3} \mathrm{H}\right]-25-\mathrm{OH}-\mathrm{D}_{3}$ to $\left[{ }^{3} \mathrm{H}\right]-1 \alpha, 25-(\mathrm{OH})_{2}-\mathrm{D}_{3}$ (Weisman et al., 1978 ; Gray et al., 1979). It has also been shown that rat (Tanaka et al., 1979) and human (Weisman et al., 1979) placentas were able to convert $25-\mathrm{OH}-\mathrm{D}_{3}$ to $1,25-(\mathrm{OH})_{2} \mathrm{D}_{3}$ in vitro. A calcium binding protein ( $\mathrm{CaBP}$ ) has been isolated from rat (Bruns, Fausto and Avioli, 1978 ; Marche, Delorme and Cuisinier-Gleizes, 1978), mouse (Bruns and Vollmer, 1982) and human (Tuan, 1982) placentas. Specific receptors for $1,25-(\mathrm{OH})_{2} \mathrm{D}_{3}$ have been isolated from rat and human placenta (Christakos and Norman, 1980; Pike, Gooze and Haussler, 1980) and from rat yolk sac (Danan, Delorme and CuisinierGleizes, 1981). Since these structures are the organs of exchange between mother and foetus, it is suggested that one physiological role for $1,25-(\mathrm{OH})_{2} \mathrm{D}_{3}$ might be the regulation of calcium transport from the dam to the foetus. In the work reported here, we have observed the possible influence of $1,25-(\mathrm{OH})_{2} \mathrm{D}_{3}$ given to the pregnant guinea-pig on calcium transfer from the dam to the foetus.

Correspondence to: J.-P. BARLET - I.N.R.A. Theix, 63110 Beaumont, France. 


\section{Materials and methods.}

Animals. - Guinea-pigs of the Dunkin-Hartley strain were used. In our colony delivery takes place 68 days after mating. During estrus a female guinea pig was caged with a male for $24 \mathrm{~h}$, so that the beginning of gestation was known within $\pm 12 \mathrm{~h}$. Primiparous pregnant females were detected by palpation one month later. Only those bearing 2 or 3 foetuses were used to avoid any important influence of litter size on calcium placental transfer (Symonds et al., 1978). They were housed in individual cages and fed ad libitum a diet for guinea pigs (Usine d'Alimentation Rationnelle, Villemoisson-sur-Orge). The calcium, phosphorus, magnesium and vitamin $\mathrm{D}_{3}$ contents of the diet were $1.1 \%, 1.2 \%$, $0.3 \%$ and $2000 \mathrm{lU} / \mathrm{kg}$, respectively. Maternal body weight, less foetal tissue, was $1.1 \pm 0.1 \mathrm{~kg}$ (mean \pm SEM).

Treatments and surgery. - Three groups of 10 pregnant 15 treated + 5 control) female guinea pigs were used, one group on each of days 40,50 and 66 of gestation. Treated females were injected intramuscularly with $1,25-(\mathrm{OH})_{2} \mathrm{D}_{3}$ $10.05 \mu \mathrm{g} / \mathrm{kg} \mathrm{bw} /$ day in propylene glycol) for the preceding 10 days. Control animals received, by the same route, an equal volume of propylene glycol $(0.1 \mathrm{ml} / \mathrm{kg} \mathrm{bw} /$ day). At the appropriate stage of gestation the guinea pigs were anesthetized by intraperitoneal injection of pentobarbital sodium ( $50 \mathrm{mg} / \mathrm{kg} \mathrm{bw}$ ). A polyethylene catheter (Biotrol $n^{\circ} 3$ ) filled with heparinized $0.9 \% \mathrm{NaCl}$ was then inserted into the maternal left carotid artery and right jugular vein.

Measurement of the placental transfer of calcium. - The procedure used to measure calcium transfer from the dam to the foetus was that employed by Wasserman et al. (1957) in rats and rabbits and modified by Twardock (1967) for guinea pigs. Briefly, $40 \mu \mathrm{Ci}{ }^{45} \mathrm{Ca}$ as chloride, diluted in $0.3 \mathrm{ml} \mathrm{NaCl}(0.9 \%)$, was injected into the jugular catheter at zero time and the transfer rate during the experimental period was calculated by dividing the total radioactivity transferred to the foetus during this period by the mean specific radioactivity of the plasma calcium during this same period.

$$
\text { Thus } \mathrm{Ca}_{\mathrm{f}}=\frac{\left({ }^{45} \mathrm{Ca}_{\mathrm{f}}\right)\left(\mathrm{Ca}_{\mathrm{mp}}\right)}{{ }^{45} \mathrm{Ca}_{\mathrm{mp}}}
$$

where $\mathrm{Ca}_{\mathrm{f}}$ is the total calcium transferred from dam to foetus during the experimental period; ${ }^{45} \mathrm{Ca}_{\mathrm{f}}$ is the total ${ }^{45} \mathrm{Ca}$ found in the foetus at the end of this period ; ${ }^{45} \mathrm{Ca}_{\mathrm{mp}}$ is the average ${ }^{45} \mathrm{Ca}$ concentration in maternal plasma during the experimental period and $\mathrm{Ca}_{\mathrm{mp}}$ is the calcium concentration of the maternal plasma.

The mean plasma calcium specific radioactivity during the $0-30$ or $0-90 \mathrm{~min}$ experimental period was calculated from the radioactivity of 6-10 arterial blood samples $(0.7 \mathrm{ml})$ taken at regular intervals throughout the period. The number of blood samples taken depended on the duration of the experiment (30 or $90 \mathrm{~min}$ ) which itself was varied because work by Twardock (1967) has shown that the return of calcium from foetus to dam following ${ }^{45} \mathrm{Ca}$ injection varies according to stage of gestation, there being no significant return 30,30 and $90 \mathrm{~min}$, respectively, after ${ }^{45} \mathrm{Ca}$ injection on days 40,50 and 66 of gestation. 
Foetuses and placentas of 40, 50 and 66 days were removed by laparotomy and hysterotomy. Foetal blood samples were collected by cardiac puncture. Foetuses and placentas were weighed, dry ashed at $500{ }^{\circ} \mathrm{C}$ and dissolved in a known volume of $5 \mathrm{~N} \mathrm{HCl}$.

${ }^{45} \mathrm{Ca}$ was radioassayed in duplicate in each sample of blood plasma and in dissolved foetuses and placentas. Packed cell volume was measured in each pregnant female in the first and last blood sample: the volume of blood collected (maximum $7 \mathrm{ml}$ ) had no significant effect on packed cell volume.

Calcium and magnesium concentrations in blood plasma and in dissolved foetuses and placentas were measured by atomic absorption spectrophotometry (Perkin Elmer 400). Inorganic phosphorus was determined by colorimetry (Technicon Autoanalyser).

Results are expressed as mean \pm SEM. The statistical significance of differences observed between treated and control animals was evaluated using Mann and Whitney $\mathrm{U}$ test.

\section{Results.}

The body weight of control foetuses increased from $11.2 \pm 1.1 \mathrm{~g}$ to $89.2 \pm$ $3.2 \mathrm{~g}$ between days 40 and 66 of gestation. Foetuses from 1,25- $(\mathrm{OH})_{2} \mathrm{D}_{3}$-treated females were slightly heavier than those from control guinea pigs, but this difference was only significant on day 50 of gestation (table 2).

$1,25-(\mathrm{OH})_{2} \mathrm{D}_{3}$ injections into pregnant females increased plasma calcium levels both in dams and foetuses at 40 and 50 days of gestation. Maternal plasma phosphate levels were simultaneously increased by the treatment. On day 66 of gestation foetal plasma calcium and phosphate levels were higher in treated than in control animals, although maternal plasma levels of these minerals were not significantly increased by the treatment. Plasma magnesium levels in dams and foetuses were unaltered (table 1).

Between days 40 and 66 of gestation the calcium, phosphate and magnesium contents $(\mathrm{mg} / \mathrm{g}$ bw) of control foetuses increased from $2.4 \pm 0.1$ to $9.0 \pm 0.2(\mathrm{P}<0.01)$, from $2.8 \pm 0.1$ to $6.1 \pm 0.1(\mathrm{P}<0.01)$, and from $0.17 \pm 0.01$ to $0.37 \pm 0.01(P<0.01)$, respectively (table 2 ).

The calcium content of foetuses from $1,25-(\mathrm{OH})_{2} \mathrm{D}_{3}$-treated females was greater than that of foetuses from control animals at $40(P<0.05)$ and 50 days ( $P<0.01$ ) of gestation, but no difference was observed between the two groups on day 66 of gestation (table 2). In control animals the calcium content of 50 -day-old foetuses $(4.6 \mathrm{mg} / \mathrm{g} \mathrm{bw})$ was approximately twice greater than that of 40 day-old foetuses $(2.4 \mathrm{mg} / \mathrm{g} \mathrm{bw})$. The same difference was observed between 66 day-old $(9 \mathrm{mg} / \mathrm{g} \mathrm{bw})$ and 50 day-old foetuses. However calcium transferred from dams to foetuses was about four times greater on day 50 $(1.23 \mathrm{mg} / \mathrm{h})$ than on day 40 of gestation $(0.32 \mathrm{mg} / \mathrm{h})$, but did not vary significantly between days 50 and $66(1.34 \mathrm{mg} / \mathrm{h})$ of gestation. The calcium transfer from the dam to the foetus at 40,50 and 66 days - measured during 30,30 and 90 min, respectively - was never different in treated and control foetuses. The calcium accreted to placenta was always higher in treated than in control animals 


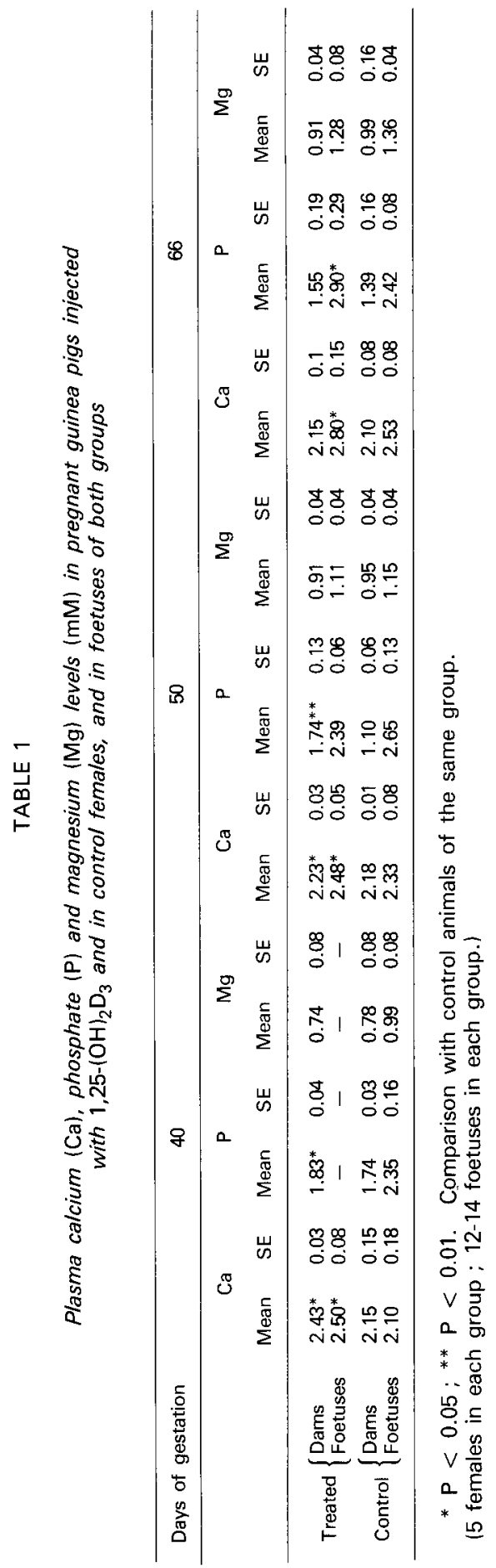




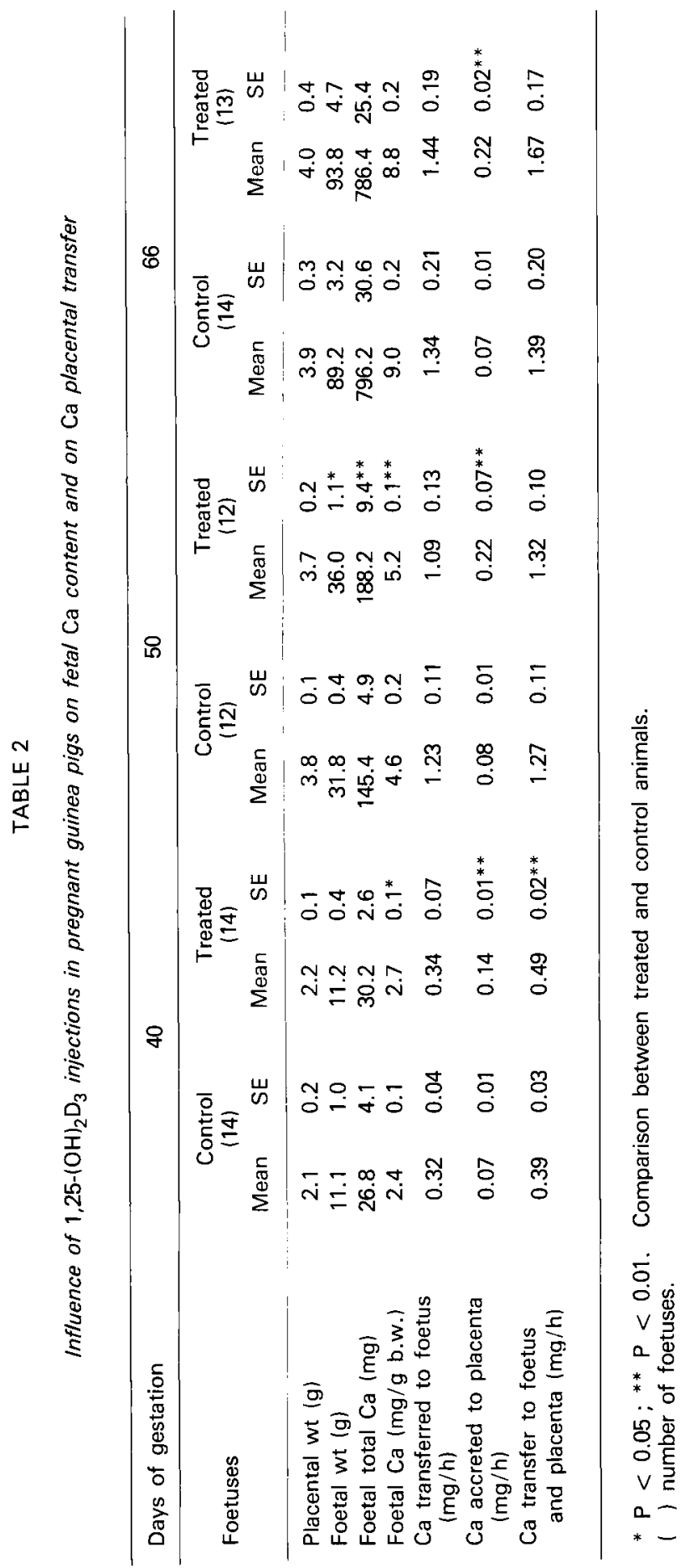


as was the total transfer to foetus plus placenta (table 2), though this was not always significant. The phosphate content of treated foetuses was greater at 40 $(P<0.01)$ and at 50 days $(P<0.01)$ than that of control foetuses. The treatment never had any significant effect on foetal magnesium content (table 3 ).

\section{Discussion.}

Under our experimental conditions, IM administration to pregnant guinea pigs of $1,25-(\mathrm{OH})_{2} \mathrm{D}_{3}(0.05 \mu \mathrm{g} / \mathrm{kg}$ bw per day) from day 40 to day 49 of gestation increased $(+4 \mathrm{~g} ; \mathrm{P}<0.05)$ the body weight of 50 -day-old foetuses (table 2 ). This increase in foetal body weight from dams treated with $1,25-(\mathrm{OH})_{2} \mathrm{D}_{3}$ is supported by the observations of Garel, Gilbert and Besnard (1981) that thyroparathyroidectomy of pregnant rats on day 12.5 of gestation induced a significant decrease in foetal weight measured on day 21.5, whereas daily subcutaneous injection of $1,25-(\mathrm{OH})_{2} \mathrm{D}_{3}$ in thyroparathyroidectomized mothers on days 17.5 , $18.5,19.5$ and 20.5 of gestation $(0.05-1 \mu \mathrm{g} / \mathrm{kg}$ bw) increased foetal weight, foetal blood glucose and foetal liver glycogen stores at term.

Plasma calcium, phosphate and magnesium levels measured in our animals are similar to those already reported in pregnant and foetal guinea pigs of the same strain (Durand, Dalle and Barlet, 1982). In guinea pigs (Twardock and Austin, 1970) as in other mammals (Kronfeld et al., 1971) the placental transfer of calcium is active. There is some evidence which suggests that placental CaBP plays a major role in placental calcium transport and that its production is vitamin D-dependent (Delorme, Marche and Garel, 1979 ; Garel et al., 1981).

In the guinea pig, the placental transfer of calcium is a two-way-process, from the dam to foetus and from foetus to dam. However, there is no back transfer of ${ }^{45} \mathrm{Ca}$ during the $30-120$ min period following ${ }^{45} \mathrm{Ca}$ injection, the exact time depending upon the age and calcium content of the foetuses (Twardock, 1967). According to Twardock (1967), the average foetal skeleton at 45 days gestation contained $106 \mathrm{mg}$ calcium and calcium was deposited at a rate of $16 \mathrm{mg} / 24 \mathrm{~h}$, whilst at 65 days the skeletal content was $954 \mathrm{mg}$ and the deposition rate $91,4 \mathrm{mg} / 24 \mathrm{~h}$. Symonds et al. (1978) demonstrated that in these animals calcium transfer rate was related to placental size, and that there was a limit to the rate of transfer, produced by a combination of limitations in placental blood flow rate, maternal plasma calcium concentrations and placental tissue transfer capacity. Values of placental transfer (from dam to foetus) obtained in our experimental conditions on days 50 or 66 of gestation $10.33 \mathrm{mg} / \mathrm{h} / \mathrm{g}$ placental tissue) (table 2) are not different from those measured by Symonds et al. (1978) in females bearing $2-3$ foetuses $(0.22-0.34 \mathrm{mg} / \mathrm{h} / \mathrm{g}$ placental tissue) on day $61 \pm 2$ of gestation.

Studies on calcium and phosphate transfer in the in situ perfused guinea pig placenta seem to indicate that acute doses of $1,25-(\mathrm{OH})_{2} \mathrm{D}_{3}$ on either the maternal or the foetal side of the placenta do not directly alter transport of these ions across the placenta (Mc Kercher, Derewlany and Raddle, 1982). However their experimental conditions were different from ours, in which a physiological dose of $1,25-(\mathrm{OH})_{2} \mathrm{D}_{3}(0.05 \mu \mathrm{g} / \mathrm{kg}$ bw per day $)$ was injected IM into pregnant 


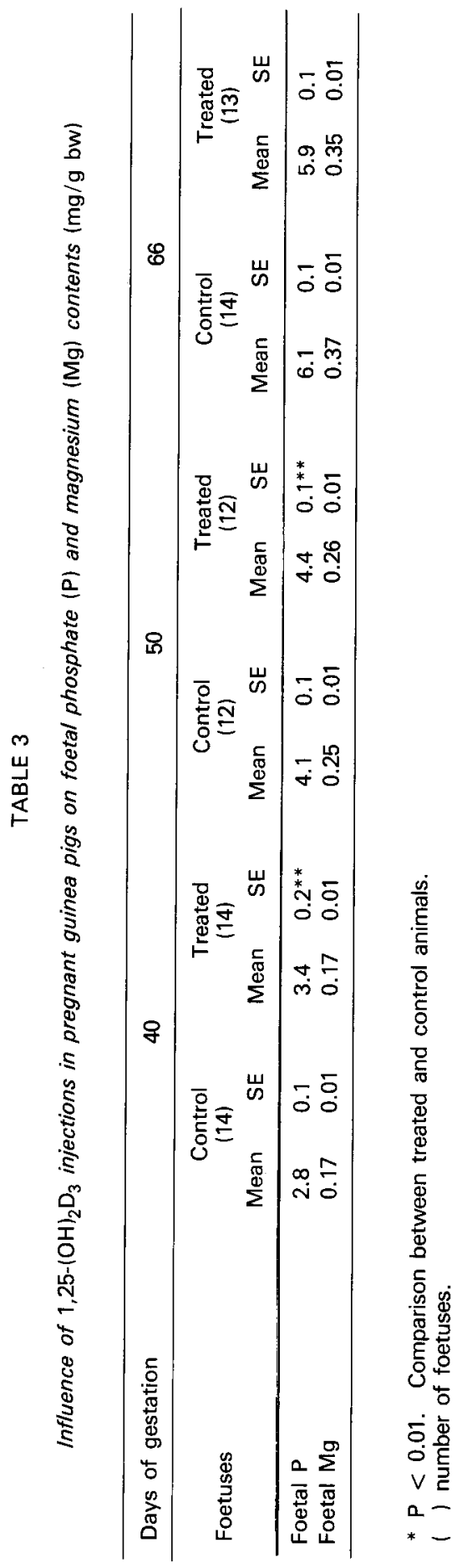


guinea pigs for 10 days. This dose of $1,25-(\mathrm{OH})_{2} \mathrm{D}_{3}$ increased significantly the rate of accretion of calcium into the placenta and the calcium content of the foetus (table 2) but had no significant effect on the rate of transfer of calcium from the dam to the foetus. The lack of effect might be due to the fact that the calcium which crosses the placental barrier remains in the placenta for a short time before deposition in the foetus. In our studies, which were of fairly short duration, measuring only foetal ${ }^{45} \mathrm{Ca}$ would not indicate total placental transfer. When transfer of Ca from dam to foetus and placenta were combined, total transfer was always higher in treated than in control animals (table 2). Studies on the mechanism of action of $1,25-(\mathrm{OH})_{2} \mathrm{D}_{3}$ on intestinal calcium transport have demonstrated that the hormone has two distinct effects. $1,25-(\mathrm{OH})_{2} \mathrm{D}_{3}$ induces a specific alteration in brush border membrane phosphatidylcholine content and structure which leads to an increase in membrane fluidity and thereby to an increase in calcium transport rate from the intestinal lumen into enterocyte. 1,25$(\mathrm{OH})_{2} \mathrm{D}_{3}$ also stimulates the synthesis of messenger RNA for $\mathrm{CaBP}$ which regulates the rate of calcium efflux from the cell across its basolateral membrane (Rasmussen et al., 1982). This might partly explain why, in short-term experiments, any increased transport of $\mathrm{Ca}$ across the placenta is shown by an increased accretion in the placenta rather than an increased transfer to the foetus. At 40,50 and 66 days, respectively, this increase to placenta is $1.8,3.2$ and $3.3 \mathrm{mg} / 24 \mathrm{~h}$. Since the total $\mathrm{Ca}$ content of the foetus at these 3 times is 27 , 145 and $796 \mathrm{mg}$, it is hardly surprising that there is no significant effect at 66 days, i.e. at 40 days an increase of $1.8 \mathrm{mg} /$ day to a total content of $27 \mathrm{mg}$ is equal to an increase of $6.7 \%$ of the total ; at 50 days an increase of $3.2 \mathrm{mg} /$ day to $145 \mathrm{mg}$ equals $2.2 \%$ of the total; at 66 days an increase of $3.3 \mathrm{mg} /$ day to $796 \mathrm{mg}$ equals $0.4 \%$ of the total.

Since we were unable to catheterize foetal blood vessels, our experimental conditions do not allow us to decide whether $1,25-(\mathrm{OH})_{2} \mathrm{D}_{3}$ injections into the pregnant mother had any effect on calcium transfer from the foetus to the dam.

In conclusion, $1,25-(\mathrm{OH})_{2} \mathrm{D}_{3}$ injections into the pregnant guinea pig increased the calcium content of the foetus. This increase was associated with a greater calcium transfer from the dam to placenta.

Reçu en septembre 1982. Accepté en octobre 1982.

Acknow'edgments. - 1,25- $(\mathrm{OH})_{2} \mathrm{D}_{3}$ used in this experiment was a gift from HoffmannLaroche (Basel, Switzerland). The authors acknowledge the assistance of R. Roux.

\section{Résumé. Influence du 1,25-dihydroxycholécalciférol sur la composition minérale corporelle} $d u$ foetus de cobaye.

L'influence du 1,25-dihydroxycholécalciférol $10,05 \mu \mathrm{g} / \mathrm{kg} \mathrm{PV} / \mathrm{j}$, injecté par voie IM pendant 10 j) sur les transferts de calcium de la mère au fœtus, a été étudiée chez 3 lots de 10 cobayes aux $40^{e}, 50^{e}$ et $66^{e}$ jours de gestation. Aux $40^{e}$ et $50^{e}$ jours le $1,25-$ dihydroxycholécalciférol augmente la teneur du fœtus en calcium et en phosphore. Les transferts fœeto-placentaires de ${ }^{45} \mathrm{Ca}$ (mesurés pendant une période variant entre 30 et $90 \mathrm{~min}$ ) sont toujours plus élevés chez les animaux traités, mais cette différence n'est significative qu'au $40^{\mathrm{e}}$ jour de gestation. 


\section{References}

BRAITHWAITE G. D., GLASCOCK R. F., RIAZUDDIN Sh., 1969. Calcium metabolism in lactating ewes. Br. J. Nutr., 23, 827-834.

BRUNS M. E. H., FAUSTO A., AVIOLI L. V., 1978. Placental calcium-binding protein in rats. J. biol. Chem., 253, 3186-3190.

BRUNS M. E. H., VOLLMER S. S., 1982. Different effects of 1,25-dihydroxycholecalciferol on calcium binding protein in the placenta and yolk sac of normal pregnant mice, 695-697. In NORMAN A. W., SCHAEFER K., HERRATH D. V., GRIGOLEIT H. G., Vitamin D. Chemical, biochemical and clinical endocrinology of calcium metabolism. De Gruyter, Berlin \& N.-Y.

CHRISTAKOS S., NORMAN A. W., 1980. Specific receptors binding proteins for $1,25-(\mathrm{OH})_{2}$ vitamin $D_{3}$ in rat and human placenta. Fed. Proc., 39, 560.

DANAN J. L., DELORME A. C., CUISINIER-GLEIZES P., 1981. Biochemical evidence for a cytoplasmic $1 \alpha, 25$-dihydroxyvitamin $D_{3}$ receptor-like protein in rat yolk sac. J. biol. Chem., 256, 4847-4850.

DELORME A. C., MARCHE P., GAREL J. M., 1979. Vitamin D - dependent calcium binding protein changes during gestation, prenatal and postnatal development in rats. J. develop. Physiol., 1, 181-194.

DURAND D., DALLE M., BARLET J. P., 1982. Plasma calcium homeostasis in the guinea pig during the perinatal period. Biol. Neonate, 42, 120-126.

FRASER D. R., KODICEK E., 1970. Unique biosynthesis by kidney of a biologically active vitamin D metabolite. Nature (London), 228, 764-766.

GAREL J. M., DELORME A. C., MARChE P., NGUYEN T. M., GARABEDIAN M., 1981. Vitamin $\mathrm{D}_{3}$ metabolite injections to thyroparathyroidectomized pregnant rats : effects on calcium binding proteins of maternal duodenum and fetoplacental unit. Endocrinology, 109, 284-289.

GAREL J. M., GILBERT M., BESNARD P., 1981. Fetal growth and 1,25-dihydroxyvitamin $D_{3}$ injections into thyroparathyroidectomized pregnant rats. Reprod. Nutr. Dévelop., 21, 961968.

GRAY T. K., LESTER G. E., LORENC R. S., 1979. Evidence for extrarenal $1 \alpha$-hydroxylation of 25-hydroxyvitamine $D_{3}$ in pregnancy. Science, 204, 1311-1313.

KRONFELD D. S., RAMBERG C. F., DELIVORIA-PAPADOPOULOS M., 1971. Active transport of calcium across placenta and mammary gland measured in vivo, 339-347. In NICHOLS G., WASSERMAN R. H., Cellular mechanisms for calcium transfer and homeostasis. Acad. Press, New York and London.

MARCHE P., DELORME A. C., CUISINIER-GLEIZES P., 1978. Intestinal and placental calciumbinding proteins in vitamin D-deprived or supplemented rats. Life Sci., 23, 2555-2562.

Mc KERCHER H. G., DEREWLANY L., RADDE I. C, 1982. Effect of calcium and 1,25-dihydroxyvitamin $\mathrm{D}_{3}$ on transfer of $\mathrm{Ca}$ and $\mathrm{P}$ across the guinea pig placenta. In Abst. of Papers, 5th Workshop on Vitamin D (Williamsburg, U.S.A., February 1982).

PIKE J. W., GOOZE L. L., HAUSSLER M. R., 1980. Biochemical evidence for 1,25dihydroxyvitamin $\mathrm{D}$ receptor macromolecules in parathyroid, pancreatic, pituitary and placental tissues. Life Sci., 26, 407-414.

RASMUSSEN H., MATSUMOTO T., FONTAINE O., GOODMAN D. B. P., 1982. Role of changes in membrane lipid structure in the action of 1,25-dihydroxyvitamin $\mathrm{D}_{3}$. Fede. Proc., 41, 72-77.

SYMONDS H. W., BUBAR R. H., CRACKEL W., TWARDOCK A. R., 1978. The effect of litter size on placental blood flow and placental calcium transfer in the multifoetal guinea pig. Br. J. Nutr., 39, 347-356.

TANAKA Y., HALLORAN B., SCHNOES H. K., DE LUCA H. F., 1979. In vitro production of 1,25-dihydroxyvitamin $\mathrm{D}_{3}$ by rat placental tissue. Proc. nat. Acad. Sci. U.S.A., 76, 50335035.

TUAN R. S., 1982. Identification and characterization of a calcium binding protein from human placenta. Placenta, 3, 145-158. 
TWARDOCK A. R., 1967. Placental transfer of calcium and strontium in the guinea pig. $\mathbf{A m}$. J. Physiol., 213, 837-842.

TWARDOCK A. R., AUSTIN M. K., 1970. Calcium transfer in perfused guinea pig placenta. Am. J. Physiol., 219, 540-545.

WASSERMAN R. H., COMAR C. L., NOLD M. M., LENGEMANN F. W., 1957. Placental transfer of calcium and strontium in the rat and rabbit. Am. J. Physiol., 189, 91-97.

WEISMAN Y., HARELL A., EDELSTEIN S., DAVID M., SPIRER Z., GOLANDER A., 1979. $1 \alpha$, 25-dihydroxyvitamin $D_{3}$ and 24,25-dihydroxyvitamin $D_{3}$ in vitro synthesis by human decidua and placenta. Nature (London), 281, 317-319.

WEISMAN Y., VARGAS A., DUCKETT G., REITER E., ROOT A. W., 1978. Synthesis of 1,25-dihydroxyvitamin D in the nephrectomized pregnant rat. Endocrinology, 103, 1992-1996. 